\title{
Premature Birth Indicator
}

National Cancer Institute

\section{Source}

National Cancer Institute. Premature Birth Indicator. NCI Thesaurus. Code C112400.

An indication as to whether the subject was born prior to 38 weeks gestation. 